Докторске студије Методике разредне наставе

ЈУ ОШ „Вук Караџић”, Власеница, Република

Српска

snezanalaketa9@gmail.com

\title{
ИНТЕРПРЕТАЦИЈА ЕПСКЕ НАРОДНЕ ПЕСМЕ ЈЕТРВИЦА АДАМСКО КОЛЕНО У ИНДИВИДУАЛИЗОВАНОЈ НАСТАВИ
}

\begin{abstract}
АПСТРАКТ: Циљ овог рада јесте представљање конкретног примера активирања ученика у настави српског језика помоћу диференцираних задатака. Посебан акценат стављен је на индивидуализовану наставу. У првом делу рада указано је на предности индивидуализоване наставе. Набројани су и облици и начини индивидуализације у настави. Један од облика индивидуализације у настави јесте и настава различитих нивоа тежине са применом задатака диференцираног типа. У другом делу рада дат је приказ интерпретације народне епске песме Јетрвица адамско колено током које су ученици решавали задатке у складу са својим знањем и способностима.
\end{abstract}

Кључне речи: народна епска песма, индивидуализована настава, диференцирани задаци.

\section{THE INTERPRETATION OF THE EPIC FOLK POEM JETRVICA ADAMSKO KOLENO IN INDIVIDUALIZED TEACHING}

ABSTRACT: The aim of this paper is to give a concrete example of activating students in teaching Serbian with differentiated tasks. A special emphasis is placed on individualized teaching. The first part outlines the benefits of this type of education presenting the forms and ways of individualization. One of the forms of individualization in teaching is teaching different levels of difficulty with the implementation of the tasks of differentiated type. The second part presents the interpretation of the folk epic Jetrvica adamsko koleno where students solve problems in accordance with their knowledge and abilities.

Key words: folk epic poem, individualized teaching, differentiated tasks.

\section{1. УВОД}

Индивидуализована настава води рачуна о претходним искуствима ученика, као и о могућностима усвајања новог знања. Она претпоставља добро познавање сваког појединачног ученика, као и планирање према интересовањима и могућностима сваког од њих. Индивидуализована настава је остварила свој циљ ако ученик у таквом раду осети задовољство. Ученик који доживи успех у односу на рад са претходног часа пожелеће да опет доживи успех. 
Рецепција песме јесте чин који се тиче лично сваког појединца и који свако проживљава на сопствени начин. Сложена структура народне песме Јетрвица адамско колено може неким ученицима представљати проблем у рецепцији, а самим тим и у доживљавању, схватању, улажењу у њене дубље структуре. Велике разлике у ученичкој рецепцији у прихватању света епске и епско-лирске песме могу се умањити индивидуализованом наставом путем решавања задатака на више нивоа тежине где ће свако од ученика, у складу са сопственим могућностима, допринети стварању једне целовите интерпретације песме. Оспособити ученике да уче, примају, да схватају свет епске песме треба да буде основни циљ наставника српског језика и књижевности. Приликом интерпретације народне епске песме ученике треба припремити да искуства посредована прочитаним текстом, искуства која доживе транспонују у продукцију нових идеја. Савременом интерпретацијом народне епске песме Јетрвица адамско колено и коришћењем индивидуализованог наставног рада ученицима ће бити приближен давни свет и живот њихових предака.

\section{2. МОТИВАЦИЈА УЧЕНИКА У ИНДИВИДУАЛИЗОВАНОЈ НАСТАВИ}

Као најзначајнија питања у раду са децом намећу се питања везана за мотивацију ученика у настави. Ако је дете довољно мотивисано лакше ће савладати препреке на које наилази у интерпретацији народне епске песме. Како заинтересовати ученике да упознају и приме у себе свет чојства, јунаштва, моралности, праведности? Народна епска и епско-лирска песма имају своју слојевитост, сложеност, специфичну структуру, језик и стил који ученицима отежавају интерпретацију. Народно песништво носи са собом и слој моралних начела, протканих историјским, друштвеним и социјалним околностима, које су окосница у тумачењу и разумевању побуда јунака. Трагично би било да због неког пропуста у припреми наставе и интерпретацији народне епске и епско-лирске песме ова велика дела не доживи сваки ученик.

Наставник који у наставном процесу успе да заинтересује ученике да га следе успешан је наставник. У интерпретацији народне епске и епсколирске песме наставник је обавезан да обезбеди све услове како би се народно наслеђе на најбољи начин пренело будућим генерацијама. Задаци који су лаки за решавање код ученика изазивају досаду, а задаци који су превише тешки доводе до одустајања. Неопходно је да наставник сваком ученику припреми задатке у складу са његовим способностима. Тиме ће повећати њихову заинтересованост и омогућити да сваки ученик доживи свет епских јунака. Решавајући задатке примерене сопственим могућностима, ученици чешће доживљавају успех, што повећава њихову мотивацију. Ако ученици често доживљавају успех, биће испуњени позитивним емоцијама, а самим тим ће и 
њихова постигнућа бити боља и значајнија. Психофизиолошки налази потврђују повезаност између емоција и мотивације:

„Настава у којој има више смјеха и позитивних емоција може, на бази лучења серотонина, код дјеце подстаћи позитивну емоционалну везаност, мотивацију. Настава као притисак и обавеза, у којој је ученик често прекидан и ометан, стимулише кортизол и сродне хормоне стреса, а тиме постаје неугода коју дијете настоји избећи, постаје демотивишућа" (Сузић 2002: 139).

За ефикасну дијагностику и индивидуализацију процеса наставе и учења одлично средство јесте Блумова таксономија,

„где сваки ученик може да отпочне свој рад на оном нивоу на коме се најбоље сналази и након тога се креће ка вишим нивоима којима тежи и што јесте циљ наставе и учења - стицати не само трајно и квалитетно знање, већ и развијати способност учења до оптималног нивоа" (Стојаковић 2000: 233).

У одељењима у којима су разлике између ученика велике неопходно је организовати наставу на више нивоа тежине где ће свако дете решавати задатке својим темпом у зависности од тога да ли је даровито или му треба помоћ у учењу. Миле Илић у свом истраживању о мишљењу наставника експериментатора о организацији наставе различитих нивоа тежине у обради књижевних текстова долази до следећих закључака:

„ученици добијају задатке које могу да реше; ученици се обучавају да уоче проблеме, формулишу питања; чешће доживљавају успех што је подстрек за бољи рад; измењен су положај и активност ученика и наставника; ученици све време интензивно раде, размишљају, осећају да сами могу да ураде; ученици су дошли до фазе самовредновања; сваки ученик има свој темпо напредовања" (Илић 1984: 126).

Индивидуализованом наставом води се рачуна о даровитим ученицима тако што им се даје импулс ка снажној мотивацији што је један од кључних фактора да, поред интелигенције и креативности, дете постане даровито. Даровитост јесте:

„производ интеракције и међузависности три елемента: изнадпросечне способности, мотивације и креативности (да се даје и креира нешто ново), и што је већа интеракција и међузависност између ова три елемента, већи је и ниво даровитости" (Стојаковић 2000: 126).

Задацима који су одмерени, али и воде даровитог ученика у зону наредног развитка, може се код ученика развити љубав ка сазнавању, јер даровитој деци је

„најчешће досадно на редовним часовима, а досада је извор највећих зала. Довољно одмереним и оптерећеним задацима, које ћемо прилагодити његовим способностима, можемо заинтересовати овакво дете” (Лакета 2011: $355)$. 
Наставник је одговоран за организацију темељне припреме задатака за даровите ученике.

\section{3. НАЧИН РЕАЛИЗАЦИЈЕ ИНДИВИДУАЛИЗОВАНЕ НАСТАВЕ}

Главни циљ индивидуализације јесте формирање позитивне мотивације за учење код ученика и ослобађање потенцијалне способности сваког појединца. У индивидуализованој настави најчешће се користе диференцирани задаци. Диференцирани задаци су прилагођени способностима ученика.

У интерпретацији песме Јетрвица адамско колено припремљени су задаци за три групе ученика - задаци на три нивоа тежине. Нивои нису одвојени један од другог, већ међу задацима постоји међусобно прожимање. Остваривање индивидуализоване наставе сложено је и могуће је

„само онда ако се испуне одређени педагошки захтеви и то: откривање и уважавање стварних разлика међу ученицима, проналажење, комбиновање и примена одговарајућих педагошких утицаја и прилаза наставном процесу у складу са постављеним циљем, прибављање адекватних наставних материјала" (Лакета 1998: 97).

Реализација овог наставног система одвија се кроз две фазе:

1. фаза: упознавање индивидуалних карактеристика појединца;

2. фаза: поступци активирања ученика у индивидуализованој настави.

Кроз упознавање индивидуалних карактеристика појединаца можемо прилагодити наставу сваком ученику.

„Идентификовање индивидуалних карактеристика представља основу диференцирања наставног процеса. Што се наставни процес више усмерава на индивидуалне вредности појединца, више се диференцијација приближава индивидуализацији" (Лакета 1998: 102).

Након упознавања карактеристика ученика започиње друга фаза поступак активирања ученика у индивидуализованој настави кроз неколико облика индивидуализације:

„1. Наставни листић;

2. Задаци на различитим нивоима тежине;

3. Елементи индивидуализације у програмираном учењу;

4. Индивидуализација у слободним и факултативним активностима;

5. Елементи индивидуализације у оквиру допунске и додатне наставе;

6. Елементи индивидуализације у оквиру групне наставе" (Илић 1984: 16). 
За интерпретацију познате народне песме Јетрвица адамско колено коришћени су задаци различитих нивоа тежине. Код задатака најнижег нивоа тежине од ученика се очекивало да одреде карактеристичне особине, осећања, изглед и поступке лика јетрвице Ковиљке. У другом, средњем нивоу очекивало се, да поред описа карактеристичних особина главне јунакиње, уоче и објасне друштвене, психолошке и моралне побуде које покрећу јетрвицу Ковиљку; затим, захтева се познавање композиционе структуре песме Јетрвица адамско колено, као и схватање стила и језика епског народног песника кроз тумачење појединих непознатих речи. У трећем, најзахтевнијем нивоу од ученика се очекивало да, поред задатака нижег нивоа које су решавали ученици, доживе и сазнају основни идејни смисао песме; решавајући задатке у којима се од њих очекује да песми дају сопствени, оригиналан наслов, чиме би, синтетишући сазнања до којих се дошло у аналитичком разговору (о теми, идејном слоју), постигли виши ниво знања и креативности.

Даровита деца врло лако могу постати незаинтересована ако је настава организована на традиционалан начин, уз коришћење фронталног облика рада и монолошке методе и ако су наставни садржаји прилагођени просечним или слабијим ученицима. У пракси се мање води рачуна о даровитим ученицима јер рад са слабијим ученицима одузима доста енергије и времена. У припреми за интерпретацију песме Јетрвица адамско колено за даровите ученике су, поред задатака трећег, најтежег нивоа, који захтева стваралачки и креативни приступ тексту, припремљени и додатни задаци за највредније, тј. за ученике који успешно реше све задатке. Они ће трагати и проналазити објашњења за речи из песме. На пример, реч Васкрс и речи које су асоцијативно повезане са њом тражиће у Српском рјечнику Вука Стефановића Караџића (Караџић 1969), а у Правописном речнику Милорада Дешића (Дешић 1998) и Практичном савјетнику Милорада Телебака (Телебак 2004) трагаће за правилно написаним речима које се односе на Васкрс - чиме се повезују настава језика и настава књижевности на један креативан и функционалан начин.

\section{4. ПРИПРЕМАЮЕ ОКОЛНОСТИ ЗА УСПЕШНУ ИНТЕРПРЕТАЦИЈУ}

Интерпретација епске и епско-лирске народне песме изискује двоструко локализовање. Потребно је поставити песму у одређени тематски циклус и повезати је са друштвеним и историјским приликама.

Песма Јетрвица адамско колено јесте песма непознатог певача, сврстана у епско-лирске народне песме, баладе. Постављањем песме у тематски круг баладе остварује се узајамна повезаност песме и баладе, и на тај начин омогућено је ученицама да нешто ново сазнају о самој песми, али и о балади као врсти. Веома је значајно да ученици уоче сличности и разлике између епске и епско-лирске песме. Историјске и друштвене прилике читамо 
из података о животу у патријархалним заједницама, с посебним акцентом на положај жене и мајке. У прошлости, патријархална заједница је имала улогу да породицу заштити од невоља и недаћа: ратова, болести, немаштине. Деца која изгубе родитеље нису препуштана судбини, већ их је родбина прихватала и одгајала. Песма која је задатак анализе управо говори о доброти, несебичности и љубави која је храна у васпитавању и одрастању деце, а услов је и за опстанак породице и читавог рода. Песма Јетрвища адамско колено пева о доброти и племенитости која не зна за границе, те по тематици која је лирска спада у баладе. Лирско-епске песме лирске теме развијају на епски начин.

\title{
а. Читање песме Јетрвица адамско колено
}

Читање је једна од најбитнијих фаза у интерпретацији народне епске и епско-лирске песме.

\begin{abstract}
„И код гласног и код читања у себи, темпо се прилагођава индивидуалним способностима ученика, те је неопходно да се усагласе потребно време и дужина текста за читање (диференцирани задаци) како би бољи читачи били довољно ангажовани све док слабији не реше свој део задатка, а да их нико не пожурује или омета на било који начин" (Вучковић 1993: 47).
\end{abstract}

За интерпретацију песме Јетрвица адамско колено неопходне су две врсте читања: интерпретативно и истраживачко. Интерпретативно читање служи да изазове пажњу, осећања, доживљај код ученика. За истраживачко читање потребно је ученицима припремити истраживачке задатке.

На почетку је потребно подсетити се обрађених епских песама. То су обично песме о Марку Краљевићу: Марко Краљевић и бег Костадин, Марко Краљевић и орао. Треба подвући основне особине јунака: јунаштво, снага, али и правичност, човечност, дирљива емотивност према орлу и птићима, праведност, заштитнички однос према сиротињи, поштовање родитеља и породице. Овде се наставник и ученици дотичу и односа у родбинским везама. Кроз буру идеја разговара се са ученицима о томе какве су им прве асоцијације када чују реч јетрва. Записују се асоцијације на табли: јетрвица јетрва, жена мужевљевог брата (девера).

Најављује се читање песме и почетак припремања самосталне анализе. Након интерпретативног читања, следи психолошка пауза. Наставник са ученицима разговара о утисцима које је песма изазвала. Следи кратко објашњавање непознатих речи:

- Ковиљка је жена адамског колена. Тако се каже за сваког човека који је попут ње племенит, који пружа љубав, указује пажњу другима и постојано подноси све животне недаће.

- Васкрсење - празник Ускрс.

\section{b. Истраживачки задаци различитих нивоа тежине}


Припремљене су три групе задатака различите тежине.

I Најнижи ниво тежине

1. Народна књижевност је настала у народу, преносила се с колена на колено и од уста до уста. Заокружи тачан одговор. $\quad$ a) тачно $\quad$ б) нетачно

2. Наведи име јетрве из песме Јетрвица адамско колено.

3. Наведи основне особине јетрвице из песме Јетрвииа адамско колено.

4. Заплака се јетрва Ковиљка,

Па говори сиротици Мирку:

„, Чедо Мирко, оди ближе стрини,

Ја не имам да загрлим сина,

А ти немаш да т' загрли мајка:

Оди, Мирко, да m' загрли стрина".

Објасни како си разумео/ла горе наведене стихове.

II Средњи ниво тежине

1. Наведи основне особине јетрвице из песме Јетрвица адамско колено. Пронађи стихове који то потврђују. Уочи и објасни, друштвене, психолошке и моралне побуде које покрећу јетрвицу Ковиљку.

2. Заплака се јетрва Ковиљка,

Па говори сиротичи Мирку:

„, Чедо Мирко, оди ближе стрини,

Ја не имам да загрлим сина,

А ти немаши да т' загрли мајка:

Оди, Мирко, да т' загрли стрина".

Објасни горе наведене стихове.

3. „Кад 'но свето Васкрсење дође,

Кад на деии рухо покројише,

Какво Мирку, онакво Маринку

Чисти скерлет и зелену свилу".

Објасни како си разумео/ла реч рухо и изнеси запажања детаља у вези са рухом из горе наведених стихова.

4. Поређај хронолошки следеће песничке слике, стављајући испред њих одговарајуће бројеве:

Разболе се невестица Винка.

А сав народ стрину благосиља.

Храни мајка два нејака сина.

— Чедо, Мирко, оди ближе стрини! 
_ Винка оставља аманет Ковиљки.

_ Обадва их оправила мајка да јој иду на цареву војску.

_ Окрете се својој милој стрини.

— Пуче пушка те уби Маринка.

— Не зна Мирко на коју ће страну.

_ Обадва је оженила мајка.

5. Приметио си да народни певач говорећи о Мирку користи реч сиротища. Објасни зашто је ова именица употребљена у женском роду.

III Највиши ниво тежине

1. Заплака се јетрва Ковиљка,

Па говори сиротици Мирку:

„, Чедо Мирко, оди ближе стрини,

Ја не имам да загрлим сина,

А ти немаши да т' загрли мајка:

Оди, Мирко, да т' загрли стрина".

Објасни како си разумео/ла горе наведене стихове. Уочи и објасни друштвене, психолошке и моралне побуде које покрећу јетрвицу Ковиљку.

2. „Кад 'но свето Васкрсење дође,

Кад на деци рухо покројише,

Какво Мирку, онакво Маринку

Чисти скерлет и зелену свилу".

Објасни како си разумео/ла реч рухо и изнеси запажања детаља у вези са рухом из горе наведених стихова.

3. Користећи Српски рјечник Вука Стефановића Караџића објасни речи аманет.

4. Користећи Српски рјечник Вука Стефановића Караџића објасни реч преслица.

5. Приметио си да народни певач говорећи о Мирку користи реч сиротица. Објасни зашто је ова именица употребљена у женском роду.

6. Поређај по реду следеће песничке слике стављајући испред њих одговарајуће бројеве:

Разболе се невестица Винка.

А сав народ стрину благосиља.

_ Храни мајка два нејака сина.

— Чедо, Мирко, оди ближе стрини!

- Винка оставља аманет Ковиљки.

Обадва их оправила мајка

да јој иду на цареву војску.

Окрете се својој милој стрини.

Пуче пушка те уби Маринка.

— Не зна Мирко на коју ће страну. 
_ Обадва је оженила мајка.

7. Промени наслов песме.

8. Објасните поводе који подстичу јетрвицу Ковиљку на велико дело.

У зависности од структуре одељења наставник може припремити додатне задатке за највредније. У овом случају, за ученике који успешно попуне листиће припремити и истраживачке задатке за чије решавање је потребно коришћење речника: Српски рјечник Вука Стефановића Караџића, Правописни речник Милорада Дешића и Практични савјетник Милорада Телебака.

1. Користећи Српски рјечник Вука Стефановића Караџића попиши и објасни све речи које су повезане са речју Васкрс:

ВЕЛИКИ ПЕТАК, ВАСКРСЕЊЕ, ФАРБАЬЕ ЈАЈА, ЈАЈА, БОЈА.

2. Користећи Правописни речник Милорада Дешића и Практични савјетник Милорада Телебака напиши правилно речи које се односе на Васкрс:

ВАСКРС, ЛАЗАРЕВА СУБОТА, ЦВЕТИ, ВАСКРШњИ.

\section{5. ИНТЕРПРЕТАЦИЈА ПЕСМЕ ЈЕТРВИЦА АДАМСКО КОЛЕНО}

Интерпретација је замишљена као систем концентричних кругова, где he се знање проширивати из круга у круг. Наставник треба динамику часа да подеси ,према истраживачким задацима, с тим што ће сваки аналитички поступак бити у служби синтетичког гледишта" (Николић 2012: 575). Извештавање ученика, изношење њихових ставова и мишљења оствариће се уз даљу садржајну анализу епске песме - проналажењем стихова, слика, поступака, али и сагледавање целокупног уметничког света песме, кроз проналажење и објашњење непознатих речи, разумевања тока радње, анализу ликова - поступака, особина, начина карактеризације.

1.

Основне податке о песми даће ученици који су решавали задатке најнижег нивоа. Главна јунакиња песме јесте јетрвица Ковиљка, коју епски певач назива адамским коленом због доброте, пожртвованости, људскости, мајчинства, моралности. Она свог синовца одгаја не раздвајајући га од рођеног сина. У овој етапи, ученици који су имали задатке средњег нивоа тежине могу се укључити проналазећи и стихове који то потврђују:

Прије Мирку бела хлеба даје,

Прије Мирку него свом Маринку;

Кад 'но света недељииа дође,

Кад изиђе на сокак међ’ друге,

Њена Мирка на крило посади,

Свог Маринка до себе на землу: 
Нитко не зна да је сиротица, А да Мирко своје мајке нема.

Врхунац те љубави, али и бола и патње исказан је у следећим стиховима: Заплака се јетрва Ковиљка,/ Па говори сиротици Мирку:/ Чедо Мирко, оди ближе стрини,/ Ја не имам да загрлим сина,/ А ти немам да m' загрли мајка:/ Оди, Мирко, да т' загрли стрина.

2.

Сложеније податке изнеће ученици који су решавали задатке средњег нивоа. Од њих се очекује укључивање у дискусију и изношење резултата и нижег и вишег нивоа, уз изношење сопственог мишљења. Стављајући одговарајући број испред песничке слике, добијамо план композиције који се може по потреби још допуњавати:

__ Храни мајка два нејака сина. Обадва је оженила мајка.

__ Разболе се невестица Винка.

__ Винка оставља аманет Ковиљки.

__ А сав народ стрину благосиља.

__ Обадва их оправила мајка да јој иду на цареву војску.

__ Пуче пушка те уби Маринка.

__ Не зна Мирко на коју ће страну.

__ Окрете се својој милој стрини.

__- Чедо, Мирко, оди ближе стрини!

Народни певач говорећи о Мирку користи реч сиротица. Могуће је понудити више објашњења зашто се ова реч користи у женском роду. Тражећи објашњење за ову реч у Вуковом Српском рјечнику, проналазимо да нас Вук упућује на реч сирота, сиротан; значи сиротица је деминутив од речи сирота. Због саме структуре десетерца епски певач је понекад вршио избор речи које ће се и тематски и структурно уклопити у стих. Коришћењем деминутива жели нас додатно разнежити, пробудити код нас осећања, саосећања према нејаком бићу. Деминутивом се користи и када јетрву назива јетрвица са циљем да укаже на њено нежно срце. А у стиховима: кад Маринку справиш кошуљииу,/ моме Мирку закрпи траљииу - нек се знаде да је сиротииа, поред риме, имамо и понављање гласа $u$ који умекшава ове речи, а код читаоца изазива емпатију.

Одговоре и запажања, који се односе на најсложеније задатке, који захтевају дубљу анализу, изнеће ученици који су решавали задатке највишег 
нивоа. Уз реч преслица у Српском рјечнику Вука Стефановића Караџића, дата је реч преља. Преслица је справа за предење. Значи, Ковиљкина и Винкина свекрва била је преља, а децу је отхранила својим занатом. Уз реч аманет у Српском рјечнику стоји пар објашњења: аманет ти Божији моја дјеща; оставио код юега новие на аманет; изио туђ аманет; Аманет ти моја царевина/ И аманет мој нејак Урошу. У песми реч аманет значи поверавање детета на чување, ослањајући се на част и поштење особе којој је дете поверено.

Мењајући наслов песме, ученик схвата њену суштину и њену поуку. Могући други називи песме су: Мајка Ковиљка, Сиротица Мирко, Ковиљка је сриа милостива, Храни мајка оба своја сина, а наслов може бити садржан и у стиховима: Тешко свуда своме без својега. Објашњавајући поводе који подстичу јетрвицу Ковиљку на ово велико дело, дубоко пониремо у песму и њене стихове: Она знаде шта је сиротињство/ (Од малоће сиротица била), затим у стихове у којима и певач и народ и сам Бог благосиљају стрину:

А сав народ стрину благосиља

(Сам ли Господ из небеског ияарства):

Ој, Ковиљка, колено адамско!

Проста душа твојих родитељь,

Који су те породили мудру,

Међ' туђу те браћу отправили,

Па ти знадеш ита је сиротињство.

У овом благослову крију се и поруке. Овде повезујемо човечност из ове песме са моралним поукама из песме Марко Краљевић и бег Костадин. Уочавамо сличности у појединим мотивима: мотив пружања помоћи слабијима, сиротима; мотив поштовања старијих; мотив поштовања родитеља и мотив уважавања породице и традиције.

Појам баладе објаснити у завршници аналитичког разговора. Лирскоепске песме обухватају песме у којима су лирске теме развијене на епски начин. Јетрвица, адамско колено пева о доброти и племенитости која не зна за границе. Балада је потресна, тужна песма.

Понављањем порука и тумачењем појединих слика и поступака са записивањем најбитнијих елемената у току претходног рада заокружује се интерпретација песме.

\section{6. ЗАКЉУЧАК}

Народна песма јесте уметничко дело, а као „уметничко дело тражи субјективне реакције у већој мери него објективно адекватне утиске; оно се упознаје кроз доживљаје који се међусобно могу веома разликовати" (Мркаљ 2008: 72). Подстицање и коришћење различитости доживљаја као богатства у интерпретацији песме Јетрвица адамско колено може се успешно остварити индивидуализованом наставом. 
Велике су могућности у организовању оваквог вида наставе, али то не значи да у наставном процесу треба занемарити и друге облике организовања који су можда у неким ситуацијама погоднији за коришћење.

У интерпретацији песме Јетрвица адамско колено коришћена су три нивоа истраживачких задатака. Од најбољих ученика се тражило да дају нови наслов песми, а то је уједно и најбољи начин да се провери да ли су разумели песму, да ли су схватили шта је порука песме и наравно да се провери њихова креативност. Њихови задаци су и најобимнији и обухватили су и задатке нижих нивоа у себи. Задаци за добре су мало лакши, али садрже елементе који ће их подстаћи на размишљање. Они треба да поређају по редоследу догађаје из народне епске песме, али и да продру у побуде главне јунакиње. Задаци за слабије ученике су много једноставнији, захтевају једноставна објашњења и описе. За организацију оваквог часа неопходно је добро познавање сваког појединачног ученика, његових способности, знања, интересовања.

Мудрост наставника огледа се у правилном одабиру одговарајуће стратегије наставе, јер, и поред предности које индивидуализована настава има, у школи је она успешна једино у комбинацији и са другим начинима рада. Свако дете у себи носи исконску потребу да сазнаје, а задатак наставника јесте да ту потребу покрене.

\section{ЛИТЕРАТУРА}

Вучковић, М. (1993). Методика наставе српског језика и књижевности. Београд: Завод за уџбенике и наставна средства. [Vučković, M. (1993). Metodika nastave srpskog jezika $i$ književnosti. Beograd: Zavod za udžbenike i nastavna sredstva]

Дешић, М. (1998). Правопис српског језика: приручник за школе. Земун: Нијанса. [Dešić, М. (1998). Pravopis srpskog jezika: priručnik za škole. Zemun: Nijansa]

Илић, М. (1984). Учење и настава различитих нивоа тежине. Сарајево: Свјетлост, ООУР Завод за уџбенике и наставна средства. [Ilić, M. (1984). Učenje i nastava različitih nivoa težine. Sarajevo: Svjetlost, OOUR Zavod za udžbenike i nastavna sredstva]

Лакета, Н. (1998). Учитељ-наставник-ученик. Ужице: Учитељски факултет. [Laketa, N. (1998). Učitelj-nastavnik-učenik. Užice: Učiteljski fakultet]

Лакета, С. (2011). Компјутерска израда мапа ума за рад са даровитим ученицима, у Реинжењеринг пословних процеса у образовању, ур. Алемпије Вељовић. (Чачак: Технички факултет): 354-360. [Laketa, S. (2011). Kompjuterska izrada mapa uma za rad sa darovitim učenicima, u Reinženjering poslovnih procesa u obrazovanju, ur. Alempije Veljović (Čačak: Tehnički fakultet): 354-360]

Мркаљ, 3. (2008). Наставно проучавање народних приповедака и предања. Београд: Друштво за српски језик и књижевност Србије. [Mrkalj, Z. 
(2008). Nastavno proučavanje narodnih pripovedaka i predanja. Beograd: Društvo za srpski jezik i književnost Srbije]

Николић, М. ( 2012). Методика наставе српског језика и књижевности. Београд: Завод за уџбенике. [Nikolić, М. (2012). Metodika nastave srpskog jezika i književnosti. Beograd: Zavod za udžbenike]

Стефановић Караџић, В. (1969). Српски рјечник. Београд: Нолит. [Stefanović Karadžić, V. (1969). Srpski rječnik. Beograd: Nolit]

Стојаковић, П. (2000). Даровитост и креативност. Српско Сарајево: Завод за уџбенике и наставна средства. [Stojaković, P. (2000). Darovitost $i$ kreativnost. Srpsko Sarajevo: Zavod za udžbenike i nastavna sredstva]

Сузић, Н. (2002). Емоције и циъеви ученика и студената. Бања Лука: ТТцентар. [Suzić, N. (2002). Emocije i ciljevi učenika i studenata. Banja Luka: TT-centar]

Телебак, М. (2004). Практични језички савјетник. Српско Сарајево: Завод за уџбенике и наставна средства. [Telebak, M. (2004). Praktični jezički savjetnik. Srpsko Sarajevo: Zavod za udžbenike i nastavna sredstva]

Snežana S. Laketa

University of Kragujevac

Faculty of Pedagogy - doctoral studies Methodology of class teaching, Užice

Elementary school Vuk Karadžić, Vlasenica

snezanalaketa9@gmail.com

\section{THE INTERPRETATION OF THE EPIC FOLK POEM JETRVICA ADAMSKO KOLENO IN INDIVIDUALIZED TEACHING}

\section{Summary}

Individualized teaching takes into account previous student experiences, as well as the possibilities of acquiring new knowledge. It presupposes a great knowledge of each student, as well as planning according to the interests and abilities of each student. Individualized teaching has achieved its goal if the student experiences satisfaction in such work. The reception of the poem is an act concerning each individual and the way they interpret it. The complex structure of the folk poem Jetrvica adamsko koleno may present a problem in the reception to some students and, therefore, also in experiencing, understanding, entering into its deeper structure. Great differences in student reception in accepting the world of epic and epic-lyric poems can be reduced by individualized teaching by solving tasks at a higher level of difficulty, where each student will, in accordance with his or her own possibilities, contribute to the creation of a complete interpretation of the song.

In the interpretation of the poem Jetrvica adamsko koleno three levels of research tasks were used. The best students were asked to give a new title to the poem and that is also the best way to check if they understood the poem, whether they understood what the message of the poem was and to check creativity. At the same time, their tasks are the most 
comprehensive and they also include lower level tasks in themselves. Tasks for the average students are a bit easier, but they contain elements that will stimulate thinking. They need to sort out in a sequence an event from a folk epic poem, but also to penetrate into the main heroine's initiatives. The tasks for weaker students are much simpler and they require simple explanations and descriptions. For the organization of this kind of class, it is necessary to fully know each student, their abilities, knowledge, and interests.

Key words: folk epic poem, individualized teaching, differentiated tasks.

Примљено: 24. 4. 2018.

Прихваћено: 30. 7. 2018. 